\title{
Lexis
}

Journal in English Lexicology

$12 \mid 2018$

Lexical and Semantic Neology in English

\section{The Neological Functions of Disease Euphemisms in English and French: Verbal Hygiene or Speech Pathology?}

Denis Jamet

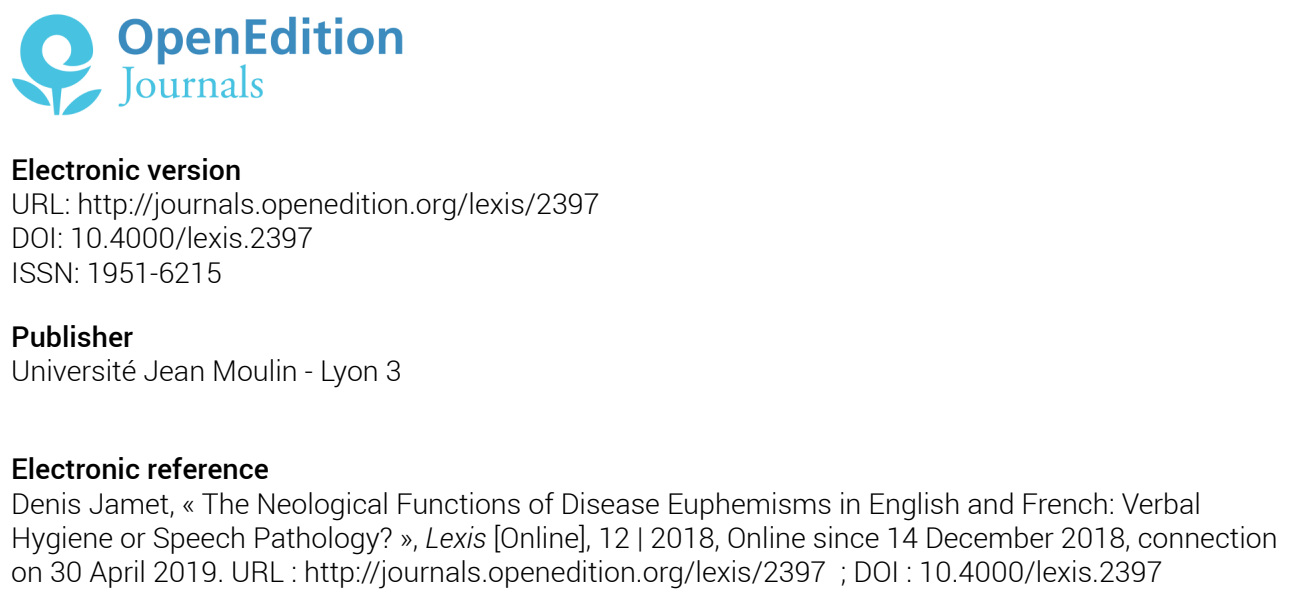

This text was automatically generated on 30 April 2019.

\section{(c) (i) ()}

Lexis is licensed under a Creative Commons Attribution-NonCommercial-NoDerivatives 4.0 International License. 


\title{
The Neological Functions of Disease Euphemisms in English and French: Verbal Hygiene or Speech Pathology?
}

\author{
Denis Jamet
}

\begin{abstract}
Euphemisms are embedded so deeply in our language that few of us, even those who pride themselves on being plain speakers, ever get through a day without using them. [Rawson
\end{abstract}

1981: 1]

As politeness increases, some expressions will be considered too gross and vulgar for the delicate. [Preface to Samuel Johnson's 1755 A Dictionary of the English Language]

\section{Introduction}

1 "Illness is the night side of life, a more onerous citizenship. Everyone who is born holds dual citizenship, in the kingdom of the well and in the kingdom of the sick. Although we all prefer to use only the good passport, sooner or later each of us is obliged, at least for a spell, to identify ourselves as citizens of that other place": this quotation from American writer and cancer survivor Susan Sontag [1990: 3] shows that diseases and illnesses are commonly associated with decay, loss of control and the fear of death, three notions generally linked to taboo language. Every human being will - one day or another, and despite medical improvements and the ever-increasing development of new cures experience some sort of brief or prolonged, benign or life-threatening affliction, and it is therefore interesting to examine what type of lexis speakers resort to when confronted with the terrifying reality that they are to come to terms with either for their own illness 
or that of a loved one. As Allan \& Burridge [2006: 203] write, "our discussion [will be] about the way people use language when expressing the emotional and social aspects of disease." The taboo surrounding illness is double - or triple - as it relies on the fear of mortality and identity loss, the shame surrounding bodily functions, and sex in the case of sexually-transmitted diseases. We will see that the taboo translates linguistically through an extensive use of euphemisms and dysphemisms in everyday vernacular, in public health campaigns as well as in private discourses, and that the language of diseases is rich with euphemisms and dysphemisms. Just think of the phrase healthcare in English, or services de santé in French; if no attention is paid, it may go unnoticed that the very notion of disease has completely disappeared from the negatively-connoted expressions they are substituted to - respectively medical treatment and soins médicaux - to leave room to the nouns health and santé, which are positively connoted. Think of mad house / mental hospital / (insane) asylum / looney bin in English or asile de fous / asile d'aliénés / asile de cinglés in French, which respectively became mental health institution / mental home / sanatorium / sanitarium in English and hôpital psy(chiatrique) / HP / sanatorium in French. Consciously or unconsciously, we all tend to sugar-coat unpleasant reality with sweet-talking techniques, a.k.a. euphemisms.

2 At the same time, and quite paradoxically, it is fair to say that the role of taboo and taboo language in the creation, evolution and expansion of the French and English lexicon is barely mentioned in studies on the reasons and motivations of lexical change and expansion ${ }^{1}$, a fact clearly stated for English by Kate Burridge:

Taboos, whether they be the so-called absolute taboos of Austronesia or the social taste constraints of Western-style taboos, are an enormously important force behind language change through (1) word loss (2) meaning shift of terms already in the language (via metaphor, general-for-specific, internal borrowing and so on), (3) deliberate modification of existing terms, (4) external borrowing. Word tabooing processes act as some kind of linguistic wild card and militate against the operation of regular predictable change [Burridge 2012] (emphasis is mine).

3 This article therefore intends to assess the actual role and function of taboo and taboo language - and more particularly the role of euphemisms and dysphemisms, as they are closely linked to taboos and taboo language - in neology, more particularly in the lexicon used to talk about diseases and illnesses in English and French. To do so, I will rely on the theoretical paradigms of Intercultural Pragmatics and Politeness-Impoliteness research, and mostly draw from Allan \& Burridge [1991] and Allan \& Burridge [2006] by mentioning their pivotal study on euphemisms and dysphemisms. To illustrate my point, I will resort to the taboo language used to refer to diseases and illnesses in English and French. My corpus - or rather set of data - used to refer to physical and mental illness is composed of lexemes and phrases used to refer to diseases and illness, directly or indirectly. The lexical occurrences were retrieved from a variety of sources, such as Internet blogs, web sites, everyday conversations (in everyday life, on TV, on the radio, etc.) as well as dictionaries and corpora such as the Corpus of Contemporary American English and Sketch Engine. The article will start with a discursive presentation of how speakers use language to euphemize in discourse, to lead to an analysis based on the code, when the ad-hoc euphemistic discursive occurrences are eventually integrated into the language as neologisms per se.

In the first part (Key concepts: neologism, taboo, taboo language, euphemism, dysphemism and orthophemism), I will briefly define key concepts, such as "neologism", "taboo", "taboo language", "euphemism", "dysphemism" and "orthophemism"; then, in the 
second part (Verbal Hygiene: why is disease and illness a taboo and how do euphemisms (and dysphemisms) help us cope with the taboo?), I will try and understand why diseases and illnesses were and are indeed still tabooed nowadays and why they give rise to a rich taboo language in French and English; I will also show that many names of diseases were originally euphemistic - all the more as they were lethal and/or associated with moral depravity or sex - but paradoxically, the more euphemistic the expression is to start off with, the more likely it is to give way to negatively-connoted, dysphemistic expressions, mostly metaphors (see Sontag [1990]). I will finally try and show in the third and concluding part why and how taboo language participates in the lexical expansion of French and English (What's in a name? (Re)inventing illness and disease through euphemistic language), where I will reflect on the various word-formation processes used to generate the taboo language used to refer to physical and mental illnesses in French and English.

\section{Key concepts: neologism, taboo, taboo language, euphemism, dysphemism and orthophemism}

5 Expanding the lexicon through neology is a frequent, never-ending phenomenon necessary for any language to evolve and be a relevant means of talking about the surrounding world. Following the tenets and previous works of Cognitive Linguistics (see Fauconnier [2002 (1997)], Katz, Cacciari, Gibbs \& Turner [1998], Kövecses [2002], Lakoff [1987], Lakoff \& Johnson [1980], Langacker [1987], Sweetser [1990], to name but a few) I postulate that language is the tool used to organize our perception of the world, and therefore to make sense of it through language, more than a mere device enabling human beings to talk about the surrounding world. More than mere labels stuck to objects, people or notions, words are representations of the world, and of the way we conceive the world we live in, and are a means of making sense of it. Words have to be understood as snapshots of society, or rather as snapshots of the way we think of society. The creation of new lexemes or phrases - referred to as "neologisms" - is the main way of expanding the lexicon in any language. A neologism is generally defined as a new lexeme or phrase entering a given language, or a new meaning taken by an existing lexeme or phrase in a given language.

6 Many linguists have proposed their own typology to classify word-formation processes (such as Bauer [1993 (1983)], [1994 (1988)], Lipka [1990], Plag [2003] or Tournier [1985], [1991a], [1991b], to name but a few, but the role of taboo language is rarely acknowledged in lexical creation and expansion. Before giving a few examples to illustrate my point, I want to give a brief definition of "taboo", borrowed from Allan \& Burridge:

Taboo is a proscription of behaviour that affects everyday life.

$[\ldots]$

Taboos arise out of social constraints on the individual's behaviour where it can

cause discomfort, harm or injury. [Allan \& Burridge 2006: 1]

The term "taboo" was supposedly coined by Captain Cook, during his $3^{\text {rd }}$ voyage around the world in 1784. The term, borrowed from the Polynesian language Tongan, denoted "prohibited behavior" and applied to "all cases where things are not to be touched." Even if there is no such thing as an absolute taboo, all societies have taboos, and speakers constantly censor the language they use to avoid mentioning them. Burridge [2004: 199] defines the word "taboo" as something "revolting, untouchable, filthy, unmentionable, 
dangerous, disturbing, thrilling - but above all powerful"; as we will see, all these adjectives can, one way or another, be applied to diseases and illnesses.

8 If we come back to the link between neology and taboo language, it has been shown that the noun bear in English originally meant "the brown one", or that the noun medved in Russian originally meant "honey-eater", because people thought that uttering the name of the animal would cause its appearance; the role of taboo language is generally only studied by historical linguistics and restricted to taboo language linked to superstition or religion. Yet, with examples borrowed from English and French, I would like to show that even in our contemporary western societies, taboo language is a powerful - even if often unrecognized - force - among others - to expand the lexicon, as Keyes clearly states:

Originally meant to avoid blasphemy and be polite, euphemisms are now just as likely to be a tool of cover-up and obfuscation [...].

Because what makes us uncomfortable changes with the times, there is a constant demand for new euphemisms [Keyes 2010: 12].

(E)uphemisms speak to concerns of their time [...].

The words we use and those we avoid illustrate what we care about most deeply. Euphemisms are the press secretary of values [Keyes 2010: 210-211].

Even if there is no such thing as euphemism or dysphemism as a word-formation process in French or English, taboo language - i.e. the language used to talk about taboos or to avoid mentioning taboos - plays a major role in expanding the lexicon, since it resorts to existing word-formation processes, as the third part of the article will illustrate. Lexemes such as cemetery - from the Greek word for "sleeping place" -, or obituaries - from Latin obitus, "departure, a going to meet, encounter" -, were initially euphemisms for more ominous lexemes (graveyard and death notices respectively). "Like 'cemetery,' a notable number of today's everyday lexemes began as euphemisms" [Keyes 2010: 13]. Taboos are therefore the powerhouse of the euphemism industry, and, as indicated by Mc Donald [1988: vi], "[e]uphemism is the inevitable partner of taboo".

10 Yet, the motivation behind the expansion of the lexicon and the creation of neologisms cannot be restricted to mere taboos, and other cognitive motivations such as psychological, sociological or linguistic reasons also account for the emergence of neologisms: lexical gap to be filled in, change in the vision of a given referent or notion, desire to play with the language (be humorous, feeling of in-groupness, etc.), and so on, as we will see below. Taboo language can be seen as one of the many reasons behind the expansion of the lexicon for realities or referents we feel uncomfortable with, while the various word-formation processes - be they morphological processes such as affixation, compounding, shortening, etc., or mechanisms of lexical innovation such as metaphor, metonymy, borrowing, etc. - are mere tools to generate it:

The primary social value of euphemisms is that they make it possible to discuss touchy topics while pretending we're talking about something else [Keyes 2010: 229].

11 I will illustrate my point with euphemisms and dysphemisms used to refer to diseases and illnesses. If early euphemisms were initially a means to avoid being blasphemous, they quickly became means to avoid impropriety, especially in the prelude to the Victorian era followed by the nineteenth century (for a detailed study of the links between the original taboos and euphemism, see Allan \& Burridge [2006: 1-28], Reyes [2010: 29-53], etc.). Consequently, “(a)s language grew more 'refined,' entire new areas of discourse became candidates for verbal evasion" [Keyes 2010: 41]. Some of the examples I use in this article are clearly not lexicalized, and are more ad-hoc discursive occurrences than real 
neologisms, but some of them managed to make their way through and are recorded in dictionaries of contemporary English (such as the Merriam-Webster Dictionary, the Oxford English Dictionary, etc.) or contemporary French (such as le Larousse, le Robert, etc.), be they as lexical entries or lemmas or only as citational uses or expressions given within other entries. What I will try to show in this article is that the evolution of society has an impact on the expansion of the lexicon, and that taboo language has a role to play in the neological creation and expansion of the lexicon, even if the degree of lexicalization of the lexemes and phrases used in French and English to refer to diseases and illnesses will vary - and consequently their degree of "neologicity".

Taboo language can be linguistically realized by "euphemisms" (i.e. sweet talking), "dysphemisms" (i.e. offensive talking) or "orthophemisms" (i.e. straight talking); the three terms form what is referred to as "X-phemisms" by Allan \& Burridge [1991] and Allan \& Burridge [2006]. The term "euphemism" can be defined as follows:

A euphemism is used as an alternative to a dispreferred expression, in order to avoid possible loss of face: either one's own face or, through giving offence, that of the audience, or some third party [Allan \& Burridge 1991: 11] (emphasis in the original text).

13 The word "alternative" seems to imply that there is always a choice for speakers, according to the situation of utterance, the interlocutor(s), the register, etc. A euphemism is generally considered to be a way to soften down, to sugar-coat a reality or referent deemed too unpleasant, harsh, coarse or difficult to accept by resorting to a softer version, as noted by Kany:

(Euphemisms are) the means by which a disagreeable, offensive or fear-instilling matter is designated with an indirect or softer term. Euphemisms satisfy a linguistic need. For his own sake as well as that of his hearers, a speaker constantly resorts to euphemisms in order to disguise an unpleasant truth, veil an offence, palliate indecency [Kany 1960: V].

14 The word "euphemism" comes from Greek euphèmismos, which is itself derived from the adjective euphèmos, "of good omen" (from eu, 'good', and phèmi, 'I say'). A euphemism linguistically consists in replacing the original signifier, perceived as being offensive or unpleasant by another signifier, perceived as softer, politer, and less offensive or derogatory. According to Keyes [2010: 4], "[u]sing euphemisms is the verbal equivalent of draping nude statues. Doing so substitutes unthreatening words for one that makes us fidget". I refer to euphemisms as "veils" or "shrouds" [Jamet 2010] thrown over the signified, as if to conceal it, but linguists have come up with a myriad of terms to refer to them: deodorant of language [Adams 1985: 48], deodorizing spray and perfume [Allan \& Burridge 1991: 25], social lubricant, shield [Allan \& Burridge 1991:3], diplomatic cologne [Crisp 1984], comfort words [Keyes 2010: 6], diplomatic language [Keyes 2010: 6], linguistic figleaves [Rawson 1981], verbal evasions [Keyes 2010: 4], verbal camouflage [Keyes 2010: 194], linguistic Prozac [Keyes 2010: 198], oblique language [Keyes 2010: 31], etc. Each of those terms highlights a specific aspect of euphemisms: for example, the term social lubricant focuses on the social function played by euphemisms, which can only be generated and thrive in a given social context, when the term comfort words rather emphasizes the relationship between the locutor and the interlocutor. Euphemisms are therefore generally considered "Face Flattering Acts" (see Brown \& Levinson [1987]) and do their best not to call a spade a spade. 
"Dysphemisms" are the opposites of "euphemisms", and therefore refer to dirty words, insults, derogatory, harsh or impolite words, and they are consequently considered "Face Threatening Acts" (see Brown \& Levinson [1987]); they can be defined as follows:

A dysphemism is an expression with connotations that are offensive either about the denotatum or to the audience, or both, and it is substituted for a neutral or euphemistic expression for just that reason [Allan \& Burridge 1991: 26] (emphasis in the original text).

In 1987, Brown \& Levinson proposed a "politeness model" based on the previous works of Erving Goffman [1955] and Paul Grice [1975], respectively including the notion of "face", and the concept of "conversational logic". Here is how Goffman defined the notion of 'face':

The term face may be defined as the positive social value a person effectively claims for himself by the line others assume he has taken during a particular contact. Face is an image of self, delineated in terms of approved social attributes [Goffman 1955: 213].

This concept can be subdivided into two different types of face: the positive face, which consists mainly in the desire to be accepted by others, and the negative face, the need to be left alone and have one's actions unimpeded by others. Brown \& Levinson have stressed that "face" is a universal concept:

[I]t is intuitively the case that certain kinds of acts intrinsically threaten face, namely those acts that by their nature run contrary to the face wants of the address and/or of the speaker. By 'act' we have in mind what is intended to be done by a verbal or non-verbal communication, just as one or more 'speech acts' can be assigned to an utterance [Brown \& Levinson 1987: 65].

Brown \& Levinson [1987] constructed their model on the premise that most of what is expressed in conversations presents a threat to the addressee's face. The notion of face, positive or negative, is therefore something that everyone is trying to protect and maintain, thanks to, among many other linguistics strategies, euphemisms and dysphemisms.

19 Interestingly, Allan \& Burridge [1991] or [2006] do not offer a definition for “ orthophemism", probably because the term refers to the unmarked, i.e. neutral form, when "euphemism" and "dysphemism" correspond to the marked forms, with a specific intention and added effect in most cases. As far as denotation is concerned, there is not much difference between a euphemism, a dysphemism and an orthophemism, because what differs are the connotations (generally neutral for an orthophemism, negative and/ or humorous for a dysphemism, and positive for a euphemism). This phenomenon is referred to as "cross-varietal synonymy" by Allan \& Burridge:

The notion that different varieties of a language use different terms, with the same or substantially the same denotation, has been called cross-varietal synonymy.

[...]

Cross-varietal synonyms share the same denotation but differ in connotation [Allan \& Burridge 2006: 46].

The choice between a euphemism, a dysphemism or an orthophemism will consequently entirely depend on the speaker's point of view, and a given lexeme or phrase can be labelled "euphemism", "dysphemism" or "orthophemism" only in a given context; even in a specific context, some people will view such lexeme or phrase as a "dysphemism", when others will perceive it as a "euphemism", depending on the conditions of use, the intention of the speaker, his or her relation with the interlocutor, etc. Labelling any 
lexeme or phrase orthophemistic, euphemistic or dysphemistic will therefore depend on the context in which the lexeme or phrase is used, and the intention of the speaker. Orthophemisms, euphemisms and dysphemisms are thus context-dependent, and not properties attached to a given lexeme or phrase, as clearly stated by Allan \& Burridge, who point out the discursive dimension of euphemisms and dysphemisms:

Like euphemism, dysphemism is not necessarily a property of the word itself, but of the way it is used [Allan \& Burridge 2006: 51].

The perception of the neutral, respectful or offensive nature is indeed sometimes difficult to assess and varies depending on the context of use (whether the term is used between close friends, between patients and doctors, between doctors, etc.). The perception of a given euphemism or dysphemism is therefore "context-dependent", which is coherent with the so-called "euphemism treadmill", a term coined by Pinker [2002]. In this process, neutral terms gradually become dysphemistic over time. Those dysphemisms are replaced by euphemisms, which later become orthophemisms. In other words, the "euphemism treadmill", also known as the "euphemism carousel", refers to the fact that euphemisms lose their protective power, that bad connotations drive out good connotations, leading to a pejoration or contamination of euphemisms (a.k.a. the AllanBurridge Law of Semantic Change, see Allan \& Burridge [2006: 243-244]) and to the routinization of euphemisms, as mentioned by Mc Donald [1988: vi]:

As they do so fresh euphemisms are introduced to take their places. Soon the process affects these new terms and they are displaced in turn. The inevitable life cycle of these words is as follows: euphemism, popular English, colloquialism, vulgarism, obscenity.

The following quote by Keyes clearly exemplifies this phenomenon:

"I used to think I was poor before I went to the welfare office. Then I learned I wasn't 'poor,' I was 'needy.' Then it became self-defeating to think I was needy, so they said I was 'culturally deprived.' Then 'deprived' became a bad word, and I was ' underprivileged.' Shortly afterward, instead of 'underprivileged,' I was told to think of myself as 'disadvantaged.' I am still poor, but my vocabulary has improved." [Keyes 2010: 221] (emphasis is mine).

We can attempt to retrace this euphemism treadmill for terms related to "disability" in English: the presumed original orthophemisms lame and crippled took on degrading connotations and could not be used to refer to people unable to walk normally. They were replaced by handicapped and then by disabled, which then evolved in the same way as the previous expressions. They have now given way to euphemisms such as physically challenged, differently abled, or lately to people with disabilities. The same goes for a word I mentioned in the introduction: asylum / asile originally meant "place of refuge, retreat", and was therefore positively connoted (see political asylum / asile politique); yet, its frequent combination with lunatic / de fous led to a pejoration of the euphemism, which became a dysphemism (see Allan \& Burridge [1991: 188-189]). This accounts for the fact that most euphemisms are short-lived and quickly become orthophemisms or dysphemisms, as the taboo they try to silence seems to contaminate them.

We will now see why, despite medical improvements and the ever-increasing development of new cures, illnesses and diseases are still very much tabooed in French and English, and how euphemisms act as "verbal hygiene" to help us cope with the taboo. 


\title{
2. Verbal Hygiene: why is disease and illness a taboo and how do euphemisms (and dysphemisms) help us cope with the taboo?
}

\author{
2.1. Brief etymological account of the words "disease", "illness", \\ "sickness" and "maladie"
}

Euphemisms are essential in conserving implicit laws of decency and social decorum when mentioning disease and illness, as the latter are often shrouded in unease and secrecy. Indeed, who has never thought twice about the proper language to use when talking about a given disease to someone who must live with it on a daily basis? What, then, is so shameful about having a disease, be it curable or not, and talking about it?

Let us first have a look at the existing words in English and French and at their etymology. Various words can be found in English: "disease", "illness" and "sickness", when only one word "maladie" is generally used in French ${ }^{3}$.

The origin of the word "illness" is revealing, as it highlights the malevolent nature of the condition: it is composed of the adjective ill ("morally evil; offensive, objectionable", according to etymonline.com) + the nominal suffix -ness. "Sickness" is the combination of the adjective sick ("unwell", Old English seoc "ill, diseased, feeble, weak; corrupt; sad, troubled, deeply affected", from Proto-Germanic *seukaz, of uncertain origin) + the nominal suffix -ness. The term "disease", often used originally for infectious diseases, is defined by the Dorlands Illustrated Medical Dictionary [1994] as "a definite pathological process [i.e. changes in body tissues and organs] having a characteristic set of signs and symptoms." Diseases are therefore dysfunctions of the human body; they cause discomfort, uneasiness and pain and may even lead to death. Likewise, Allan and Burridge [2006: 203] define diseases as "accidents" or "happenings" of the body, in the sense of something happening randomly (cf. by accident). The word "disease" itself used to be a euphemism. It comes from dis "cease" and ease "be comfortable". The same goes for French, and the etymologies of the words malade and maladie are revealing: malade comes from Latin male habitus (literally mal portant i.e. in bad health), but the initial words to refer to malade and maladie were Latin morbus (mal, maladie, but also dépravation, débauche, vice) and Latin aeger (malade, fatigue, triste, affligé). The word morbus first disappeared, because it sounded too much like mors (death, corpse) and was replaced by words such as infirmitas, languor, valetudo; the word aeger was also replaced by the following euphemisms: infirmus, gravis, languidus. Then, the euphemism male habitus came with vulgar Latin, giving malade and maladie in French. As a result of that, talking about diseases is never an easy thing, and speakers usually resort to euphemisms. It is interesting to note that today another euphemism seems on its way in English, as we sometimes talk about "discomfort" or "condition" instead of "disease", and even in French when we talk of un (petit / léger / grave) problème / souci / ennui de santé instead of une maladie. There is thus evidence to suggest that the relation between euphemism and the vast array of pathological medical conditions referred to as disease go a long way, all the more as diseases are at the crossroads of various taboo domains: body, death and sex. Depending on the type of disease, the taboo domain will vary. For instance, the taboo around venereal diseases is not a taboo about death, like cancer, but a taboo about sex. 

because of its sexual origins, and the moral depravity it was supposed to cause, hence the euphemism cupid's measles. It was usual for people to blame the foreigners for the sexual deviance it supposedly came from, hence names such as Spanish needle, Spanish pox, Spanish pip, Spanish gout, the disease of Naples, Naples canker, then in the $18^{\text {th }}$ century the malady of France, French pox, French disease, French aches, French fever, French malady, French gout, and French marbles. You were Frenchified if struck by syphilis and knocked with a French faggot if your nose had been destroyed by syphilis (Allan \& Burridge [2006: 206-207]). 
Leprosy was also a much-tabooed disease associated with lust and sexual misdemeanors, and was seen as a punishment from God, as "the horrible disfigurement of lepers was felt to reflect an inner corruption and mental derangement" [Allan \& Burridge 2006: 208].

The impressive technical breakthroughs of medicine in the $20^{\text {th }}$ century established more reliable knowledge about the causes of various diseases and illnesses and rendered a many unfounded beliefs and superstitions of the past obsolete. Or did they? Indeed, diseases and illnesses are still tabooed nowadays for two main reasons:

- Because they can be lethal: cancer, AIDS, etc.

- Because they imply fear ${ }^{5}$ (see scared to death, worried sick / mort de peur, malade d'inquiétude), ignorance, and lack of control ${ }^{6}$ (see lose one's mind / perdre la tête), which gives rise to a myriad of euphemisms, all the more so for the diseases implying loss of control (Alzheimer's disease, Parkinson's disease, cancer, etc.).

Some of today's most serious diseases - especially those associated with death or degeneracy, such as cancer, AIDS and Alzheimer's - are still much-tabooed and resort to various euphemisms. Indeed, with diseases, there are many reasons why one would prefer to use a euphemism:

- Not to mention the name of the disease for superstition-related reasons,

- Not to make someone uncomfortable when mentioning their condition,

- Not to impose one's condition on others when mentioning one's own condition, etc.

Let us conclude this part with a few words on mental illness; Allan \& Burridge [1991:186-187] make it clear that mental illness is somewhat different from physical illness and more difficult to apprehend:

$[\mathrm{M}]$ ental illness still has a great deal of mystery to it. For one, it is nowhere near as easy to define as physical illness. The term covers an enormous assortment of conditions, ranging from mildly eccentric or neurotic behavior, to severe psychotic disorders where a patient might lose total contact with reality (as in the case of severe schizophrenia, for example). To the layperson who lumps all these together as insanity, the picture is indeed a confusing one. When is nonnormal behavior to be considered an illness? When is behavioral deviance considered problematic?

As in most cases of stigmatizing illnesses, the origins of mental illness are usually mysterious. [...] Mental illness is viewed not so much as a disease, but more as a moral failure.

Just like physical illness, mental illness is linked to fear and superstition, as well as lack of control: "the fear of becoming insane is one of the most common of fears felt by normal people, taking equal place with those of cancer and death" [Gillis 1972:177]. It is still much-tabooed, as the causes of mental illness remain mysterious, and people suffering from it are feared for that reason. Allan \& Burridge [2006: 216] retrace the origins of the expressions we use to refer to mental illness, and link them to the notion of flaw, deficiency:

The stereotypical mental patient as someone 'flawed, deficient' [...] is the basis for many other dysphemistic expressions for madness: crack-brained, scatter-brained, shatter-brained; head-case; falling to pieces; unhinged; having a screw/tile/slate loose; kangaroos in the top paddock; one brick short of load; not playing with a full deck; three cards short of a full deck; one sandwich short of a picnic; two cans short of a six-pack; two bob short of a quid; not the full quid; a shingle short; a shrub short of a herbaceous border; and perhaps he's lost his marbles.

The examples quoted by Alan \& Burridge are recorded in dictionaries and are therefore lexicalized; they belong to the linguistic code, and are not mere discursive occurrences 
but examples of disease neologisms. Obviously, there exist many other euphemisms or dysphemisms to refer to mental illness in all its forms, such as touched, chrétien (a Swiss French euphemism, different from but related to the English dysphemism cretin), deranged / dérangé/e (from "disturb", "disarrange", "disorder"), sick / malade in expressions such as "Are you sick? / T'es malade? Tu vas pas bien?"), mental (the adjective came to mean "insane", "mad" - insane being a euphemism for mad, which exhibits the pejoration of euphemisms), manquer de cuisson, etc.

In a way, euphemisms can be seen as a form of "verbal control" in the face of illness, to protect oneself from "infected language" and to put a "healthy distance" with the illness. Euphemisms intend to "quarantine" the dangerous sides of diseases, by resorting to other terms to refer to something perceived as threatening and/or embarrassing.

Even if diseases most of the time strike randomly, the very term conveys negative connotations, as previously mentioned with the etymologies of the words disease, illness and malade / maladie. Even if you think about the terms related to disease, these are also negatively connoted: patient, sufferer, victim in English, and patient/e, victim, personne atteinte de... The referents are in all cases seen as passive and seem to just put up with the situation without acting at all. Let us now examine why some diseases are more tabooed than others, and how their very names are used dysphemistically and lead to the creation of semantic neologisms.

\subsection{Why are some diseases more tabooed than others, and how come their names can be used dysphemistically?}

Following Firth's famous principle, "You shall know a word by the company it keeps" [Firth 1957:179], I now want to show that, interestingly, the names of many common diseases were originally euphemistic - all the more as they were lethal and/or associated with moral depravity or sex; yet, quite paradoxically at first sight, the greater the euphemistic origin, the more prone the names of diseases are to giving rise to negativelyconnoted, dysphemistic expressions, mostly metaphors (see Sontag [1990: 74]: "And there is a tendency to call any situation one disapproves of a disease"). In other words, when you nowadays use the name of a disease to refer to something else, the very name turns into a dysphemism: for example, the plague (Sontag [1990: 132] indicates that "[p]lague, from the Latin plaga (stroke, wound), has long been used metaphorically as the highest standard of collective calamity, evil, scourge") / un pestiféré / be treated like a leper (even if leprosy is easily cured nowadays, the stigma still exists), or une lépreuse in French, which is still the name given to a mouldering stone façade. Sontag [1990: 58] summarizes this as follows:

Feelings about evil are projected onto a disease. And the disease (so enriched with meanings) is projected onto the world.

Let me briefly illustrate my point with some occurrences drawn from the COCA (Corpus of Contemporary American English) for English and from Sketch Engine Corpora for French: I italicized the name of the disease used as a dysphemistic semantic neologism, and, following the precepts of semantic prosody, I underlined the terms shading some negative connotation in the utterances:

(1) I got my car washed while the girl listened to some truly disgusting rap song on a radio. So, I thought, rap, the AIDS of culture, has reached northern Idaho. 
(Stein Benjamin J., On location, American Spectator, Vol. 25, issue 10, October 1992, 43)

(2) The strongest reaction came from composer-arranger Julio Medagila, who had worked with the tropicalists. In his diatribe, he called rock the AIDS of popular music.

(Perrone Charles A., Changing of the guard: Questions and contrasts of Brazilian rock phenomena, Studies in Latin American Popular Culture, Vol. 9, 1990, 65)

(3) He wasn't a sex pig last month when he campaigned for Phil Murphy in New Jersey. But now that his wife has lost the presidency and Bill is under scrutiny, he is suddenly a leper to the party that enabled him for decades. Sell it somewhere else. None of us believe it. The truth is you have to question how seriously these Democratic women take sexual harassment. These are some of the same women who held a pep rally for Bill Clinton in 1998 after his impeachment.

(Condemnations Of Convenience; Clinton Accusers Speak Out; Collapse of Political Dynasties; Hillary Clinton Comments on Sexual Misconduct Allegations against Roy Moore, Al Franken, and President Trump, Ingraham Angle 10:00 PM EST, 2017 (171117 SPOK))

(4) My former supervisor had given me some advice before I was transferred to the boondocks. "Play it tough," Sgt. Kathy Frost had said. "When you're assigned to a new district, you need to come on strong, or people will think you're a pussy. Especially way Down East, where they eat wardens for breakfast." Everywhere I'd gone for the past three weeks, people treated me like a leper. Doc Larrabee was one of the lonely exceptions. Maybe he felt sorry for me, or maybe, as a recent widower living alone in an isolated farmhouse, he thought that hanging around with the hated new game warden would be the cure for midwinter boredom.

(Doiron Paul, Bad Little Falls: a novel, New York: Minotaur Books, $1^{\text {st }}$ Ed., 2012)

(5) En déroulant le tapis rouge pour l'ancien pestiféré de la communauté internationale, Nicolas Sarkozy confirme que cette première visite en France de Kadhafi depuis quatre décennies faisait bien partie du « deal » intervenu en juillet dernier.

http://luciennemagaliepons.blogspot.com/2007/12/le-colonel-kadhafiparis.html

(6) Il suffit de considérer le cas de Monsieur Vanneste, qui n'a fait que dire fort dignement et sans unanimité des choses fort justes, et qui est maintenant lâché aux chiens comme un pestiféré. Ce qu'il disait aurait été une pensée banale, modérée et polie il y a de cela vingt ans. Ses propos le vouent désormais à l'enfer - Enfin je crois que dans la société française, les hommes politiques ne sont que les alibis d'une caste de fonctionnaires.

http://philippepemezec.blogspirit.com/archive/2007/01/02/bonne-

annee-2007.html

(7) sale race qu'est l'être humain dans sa totalité... nous sommes le cancer de cette planète...

http://www.webchoc.com/videos2/spip.php?article20460

(8) Non j'aimerai qu'il gagne pour faire fermer la gueule de l'avocat de Nafissatou, parce qu'il appelle au rassemblement des communautés et je suis totalement contre le communautarisme qui est l'un des plus gros cancer (sic) de ce monde.

http://wearehnr.wordpress.com/tag/dsk/

(9) Il est le summum de l'évolution. Il est le prédateur. Il est le dévoreur de

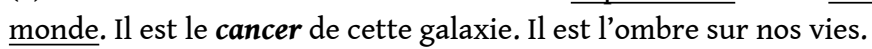

http://forum-tyranide.forumactif.org/t1676-un-organisme-parfait

(10) Le 14 janvier, environ 400 étudiants de la faculté de droit manifestent contre l'admission dans leur faculté de 62 étudiants, des rapatriés pour la 
plupart, contre les pots-de-vin allant de 2000 à 3000 dollars (11) versés aux fonctionnaires de la faculté. La corruption est le sida de la société crient les manifestants, «Ce n'est pas la démocratie, mais l'anarchie ".

http://eglasie.mepasie.org/asie-du-sud-est/cambodge/convalescence-ourechute-le-point-sur-la-situation$$
\text { for a judgment passed onto something looked upon, as Sontag [1990: 72-73] writes: }
$$

Illnesses have always been used as metaphors to enliven charges that a society was corrupt or unjust. Traditional disease metaphors are principally a way of being vehement.

$[\ldots]$

Disease metaphors are used to judge society not as out of balance but as repressive.

As Sontag [1990: 6] clearly showed, "[a]ny disease that is treated as a mystery and acutely enough feared will be felt to be morally, if not literally, contagious." She also adds:

[I]t is diseases thought to be multi-determined (that is, mysterious) that have the widest possibilities as metaphors for what is felt to be socially or morally wrong. [Sontag 1990: 61]

Long-term diseases in general, and cancer in particular, are often expressed through the war metaphor, where the disease is the enemy, the patient is the victim of an invasion, and treatment is the counterattack. This military metaphor can - at least initially - be considered a euphemism in the sense that it softens the aspect of the disease that is frightening and unknown, to focus on another aspect, the "fight", the "struggle" or "crusade" against cancer, which is the "killer" disease and patients "cancer victims". We find expressions such as fight hard, or fight back, which are not originally attached to the disease itself 7 . Let us now examine more closely the very words and expressions used euphemistically in French and English, and see how they expand the lexicon through specific word-formation processes.

\section{What's in a name? (Re)inventing illness and disease through euphemistic language}

So far, we have been examining euphemisms in discourse, i.e. the way language is used to euphemize. We are now turning our attention to the code itself, and how euphemisms are incorporated into the systems that most speakers of a language use. Now that the reasons why diseases and illnesses are still tabooed nowadays have been developed, we will see that it is relevant to consider the role of taboo and taboo language in the neological expansion of the lexicon, as Keyes writes:

An excellent way to determine what we find embarrassing is to examine our verbal evasions. They indicate what's on our minds [Keyes 2010: 4].

[...]

Euphemisms are an accurate barometer of changing attitudes [Keyes 2010: 11].

Or Burridge:

No matter which human group we look at, past or present, euphemism and its counterpart dysphemism are powerful forces and they are extremely important for the study of language change. They provide an emotive trigger for word addition, word loss, phonological distortion and semantic shift [Burridge 2012].

In their pivotal study on taboo language, Allan \& Burridge recognize the role played by euphemism and dysphemism in lexical creation and expansion: 
Taboo and the consequent censoring of language motivate language change by promoting the creation of highly inventive and often playful new expressions, or new meanings for old expressions, causing existing vocabulary to be abandoned [Allan \& Burridge 2006: 2]. object, a new concept is invented or discovered and needs to be named), or to fine-tune an existing notion (a phenomenon which is possibly often accompanied by a slight semantic shift). As Schmid [2016: 69] states:

[N]ew words are continually being added to the lexicon, generally because new objects are being invented and new ideas are arising, all requiring a designation. In addition, words which are not strictly speaking 'required' for naming purposes are created to encapsulate new trends and social practices.

As Foubert \& Lemmens [2018, this volume] clearly indicate, "[...] the need for new words highlights the social dimension of language", as society triggers changes in language, but the language we speak also shapes our apprehension of the world. Yet, as far as disease euphemisms are concerned, there does not seem to be any lexical gap to fill in, as the reality and the words to refer to it already exist; what are therefore the motivations behind the creation of euphemisms and dysphemisms, especially when it comes to refer to illness and disease?

The various reasons underlying the creation - and potential success - of euphemisms and dysphemisms depend mostly on the reasons why they are used and the types of euphemisms and dysphemisms (protective euphemisms, underhand euphemisms, uplifting euphemisms, provocative euphemisms, cohesive euphemisms, ludic euphemisms, etc. ${ }^{8}$. This means that if society plays a role in the lexical expansion of taboo language, the very context of utterance can also play a part. Basically, several functions for the creation of euphemisms and dysphemisms can be identified, but we have to keep in mind that the functions can overlap and be found together for a given lexeme or phrase:

- A desire to be polite or impolite / humorous (Face Flattering Act or Face Threatening Act, see Brown \& Levinson [1987] or Allan \& Burridge [2006: 39]);

- An argumentative function (convince the interlocutor(s) of the relevance of the new image offered by the new signifier);

- A relational function (create a feeling of in-groupness between the speaker and the interlocutor(s), create a specific identity to include some, and exclude others);

- The need to change the (vision of the) world (offer a new signifier to highlight the change in the perception of the world), as clearly stated by Pruvost \& Sablayrolles: Parfois, par identification abusive du signe et du référent, on a l'illusion qu'en changeant le nom on change la réalité. Qu'ont gagné les pauvres à devenir des économiquement faibles, les clochards des SDF, et les aveugles des déficients visuels ? [... ] Parfois aussi le changement de dénomination est la marque d'une volonté de modifier la manière de concevoir certaines réalités [Pruvost \& Sablayrolles 2012 (2003): 83].

Il y a unanimité à penser qu'une langue qui n'évolue plus est une langue morte. La langue doit pouvoir permettre de parler des nouvelles réalités qui apparaissent ainsi que des nouvelles manières d'être ou de penser de la ou des communautés qui la parlent [Pruvost \& Sablayrolles 2012 (2003): 82].

In any case, taboo language engenders some lexical expansion, which is revealing of the evolution of society, as explained by Pruvost \& Sablayrolles: 
La néologie reflète la progression d'une langue tout autant que l'évolution d'une société. [...] Le langage est daté et ce sont les néologismes qui en sont les éléments comptables les plus marquants [Pruvost \& Sablayrolles 2012 (2003): 28]. generated through a process of specialization / narrowing of meaning: the two words initially meant a place of welcome and healing for weary travelers, and share the same roots as those of "hostel", "hospice" and "hotel". The current meaning narrowed down to the purely medical meaning.

57 a) Metonymy and hypernymy: the two notions are closely linked, as most metonymies found to refer euphemistically to diseases often resort to a hypernym. A hypernym is a word that names a broad category ("disease") that includes other words ("cancer", "flu", cold", etc.). Metonymy is defined as an inclusion process between two related conceptual domains, an association of ideas by which you refer to a referent by one of its attributes, to the inventor by the invention (and vice-versa), etc. As far as names of diseases are concerned, it is especially "the name of the scientist +'s + disease" in English and "maladie + de + the name of the scientist" that are mostly used to refer to the disease orthophemistic, as the following occurrences exemplify; even if those terms are not real euphemisms, the names tend nowadays to be perceived as orthophemisms, i.e. as the prototypical way to refer to the disease; resorting to metonymy in that case is essentially for reasons linked to the denomination paradigms available at the time the disease was 
discovered, and which may vary depending on the periods and the places ${ }^{9}$. The names therefore play a role in the terminological construction of the domain, as exemplified by the examples of the first category:

(11) Hansen's disease / Maladie de Hansen (from the physicist who discovered the bacillus responsible for the disease - leprosy - in 1871)

(12) Crohn's disease (a.k.a. morbus disease) / Maladie de Crohn,

(13) Huntington's disease / Maladie de Huntington

(14) Parkinson's disease / (Maladie de) Parkinson

(15) Alzheimer's (disease) / (Maladie d')Alzheimer / un Alzheimer (a euphemism for Senile Dementia of Alzheimer type; it is interesting to note that for this degenerative disease the word "disease" is most of the time omitted, and just the name of the physicist is kept),

(16) Down Syndrom / Syndrome de Down (a.k.a. Trisomy 21; it is interesting to note that the word "disease" disappears, once again), etc.

\section{The effect or result for the disease}

(17) Consumption (= "eating up", i.e. tuberculosis), etc.

(18) Not feel too good / Ne pas être très bien (used to euphemize any minor condition),

(19) Tumor / Growth / Une tumeur / Une grosseur (especially used to euphemize the word "cancer"),

(20) Absentmindedness / Absences (Alzheimer's disease, or any senile disease),

(21) A long / prolonged / incurable illness / Une longue et douloureuse maladie / Une maladie incurable (cancer),

(22) Be sick / Etre malade (vomit),

(23) Hard-of-hearing / Avoir des problèmes d'audition (deaf),

(24) Have the runs / Have an upset stomach / Avoir la courante (have diarrhea), etc.

\section{The reason for the disease}

(25) Fièvre de Lassa (fièvre Ebola, from Lassa, a town in Nigeria) / Virus Marburg (from a town in Germany where the virus appeared in Europe) / Virus du Nil occidental, etc.

(26) French sickness / French gout (venereal disease) / Fièvre hémorragique bolivienne (typhus noir),

(27) Venereal/Venusian disease / Maladie vénérien/ne (associated with sex, but originally associated with love, as the name of Venus, the goddess of love, indicates),

(28) Social disease (venereal disease),

(29) Not doing well (dying), etc.

61 It is interesting to note that the first examples in (25) are rather neutral, and lexicalized, as the disease is located at a specific place, and the following examples (26), (27), (28) and (29) are more euphemistic, as the names of the diseases put the blame on foreigners; English and French resort to adjectives referring to nationalities or toponyms to dilute the threatening effect attached to the taboo, and to blame foreigners for the disease at the same time. The first example is clearly linked to the terminology of the domain - then to neology per se - when the others act more as discursive euphemisms.

(b) Metaphor: metaphor is an analogical process through which you notice a resemblance - or even a difference - between two conceptual domains that are logically 
unrelated at first sight. By definition, and following the precepts of Cognitive Linguistics, metaphor enables the speaker to offer a new vision of a given referent, which is in keeping with what euphemisms and dysphemisms aim to do. Even if some diseases have been named metaphorically (see cancer, a real neologism at the time of its creation), most of the occurrences below are used as substitutes to avoid mentioning the name of the disease:

(30) Cancer (from Greek karkinos and Latin cancer, "crab", because of the resemblance of an external tumor's swollen veins to a crab's legs), etc.

(31) Be under the weather / Be off-colour (GB) / Ne pas être dans son assiette,

(32) Be down in the dumps / Avoir le cafard,

(33) Be out of sorts / Être mal luné,

(34) Be green around the gills / Avoir une tête de déterré/e,

(35) Have trouble with one's waterworks (have a bladder condition) / Avoir des problèmes de plomberie (avoir des problèmes intestinaux),

(36) Be (a) lunatic (see loon, loony; from the madness supposedly caused by the changing phases of the moon) / Have kangaroos in one's top paddock (Australian: be insane) or not be sixteen annas to the rupee (Anglo-Indian: be insane) / Être cinglé/e / félé/e / barré/e / cintré/e / sonné/e / frappé/e / siphonné/ e / givré/e / timbré/e / fondu/e / Avoir un grain / Avoir un un petit vélo dans la tête / Être marteau / Yoyoyter de la cafetière,

(37) Montezuma's revenge (diarrhea), etc.

\subsection{A new signifier for an existing meaning (i.e. a new signifier is either invented, or borrowed from the actual lexicon, with a new meaning)} existing lexemes or phrases, but rather by modifying the morphology of existing ones, or by a creation per se. Disease euphemisms are therefore generated by various wordformation processes or mitigating devices, such as borrowing, shortening (clipping, acronyms and initials), rhyming slang, litotes a.k.a. negative of the contrary and circumlocution. Most of the time, the signifier will either be cut out, reduced or, on the contrary, lengthened, as if to dilute its threatening effect.

a) Borrowing: borrowing (of loan words) consists in borrowing a lexeme or phrase from a foreign language (mostly Latin, and to a lesser extent Greek) to use it in French or English or from a technical language; generally speaking, technical language - jargon, medicalese, specialized terminology, labels - generally has an orthophemistic value, and therefore plays a role in terminology, but may also become euphemistic according to the context and the intention of the speaker, as recalled by Crawford [2008]:

Medicine borrowed mainly Latin terms in order to label and discuss disease, and conversely, many of these Latinate terms were absorbed into lay terminology as euphemistic ways of referring to dreaded illnesses.

It very often results in technical terms, learned and loan words, as the lexemes are generally borrowed from classical languages which are perceived as more abstract, especially in English, therefore allowing the creation of a distance between the signifier and reality, as Neaman \& Silver [1990 (1983): 144] write:

Doctors, for example, tell us that they do not euphemize, but evidence points to the contrary. Technical, medical language, laden with Greek and Latin, may seem precise and literal to those who use it, but to the ordinary patient, it may be 
incomprehensible. Therefore, such language elevates the position of the specialist, establishing him or her as a member of a privileged and powerful secret society. Furthermore, it may conceal both the meaning and the seriousness of the illness under discussion. When a potentially fatal condition like a heart attack is called a MYOCARDIAL INFARCTION or "an MI," the terror may abate even though the pain does not. On the other hand, an EPISTAXIS seems far more dignified and worthy of medical treatment than a mere nosebleed. terminological lexemes:

(38) Myocardial infarction / Infarctus du myocarde (from Greek myo-, from

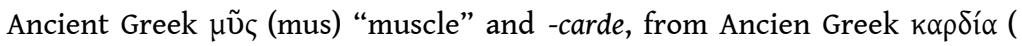
kardia), "heart",

(39) Herpes / Herpès (from Greek "a creeping"),

(40) Oncology / Oncologie (from Greek onkos, 'mass'),

(41) Mitotic chromosomal instability, Mitotic disease, Mitotis / Mitose (from Greek mitos, 'filament'),

(42) Melanoma / Mélanome (from Ancient Greek $\mu \varepsilon ́ \lambda \alpha \varsigma, \mu \varepsilon ́ \lambda \alpha v o \varsigma$ (melas, melanos ), "black" and -oma, "tumor", from Ancient Greek - $\omega \mu \alpha$ (ôma), derived from

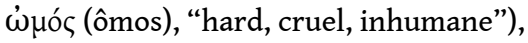

(43) Lymphoma / Lymphome (from Latin lympha, 'water', and Greek -oma, "tumor"),

(44) Neoplasm / Néoplasme (tumor, growth, from the Greek neo- "new" + Greek plasma "formation", a word coined in German and borrowed from German by English and French),

(45) Carcinoma / Carcinome (from Greek karkinôma, 'cancer'),

(46) Aprosexia / Aprosexie (pathological inability to sustain attention),

(47) Gonorrhea / Gonorrhée/Blennorragie (from Ancient Greek yovóppora ( gonórrhoia), from yóvos (gónos, "sperm, seed, offspring") + poía (rhoía, "flow"), etc.

(48) Treponemal disease / Luetic disease / Spirochaetal disease (= syphilis),

(49) Morbus disease (from Latin, Crohn's disease),

(50) Piles (= hemorrhoids, from Latin pila, "ball”), etc.

67 Finally, let us mention that English also occasionally borrowed from French: the euphemism clap, used to refer to any venereal disease (such as gonorrhea), has been borrowed from French clapoir, a word meaning "swelling".

Borrowing is thus quite a productive word-formation process both in English and in French, especially to name a disease, and thus playing a role in terminology. What is interesting is that the technical label can also become a euphemistic way to refer to the disease. Let us now examine two opposite morphological word-formation processes - i.e. shortening and circumlocution - which, surprisingly, can both be used to generate disease euphemisms.

b) Shortening (clipping, acronyms and initials): shortening is a morpho-lexical device generating mostly terminological euphemisms, as the signifier is "minced", or "cut out", and is felt to be less offensive than the corresponding orthophemism. For disease euphemisms, it is interesting to note that most of the time native speakers are unaware of the acronyms behind the term, as the motivation is completely lost ${ }^{10}$, and that they quickly become terminological labels, even if the full forms co-exist ${ }^{11}$ :

(51) AIDS / sida (it is interesting to note the upper-case spelling in English and the lower-case spelling in French, and that numerous terms in the 
AIDSpeak lexicon include acronyms: PISD, People with Immune System Disorder, PLUS, Positive Living for US, ACT UP, AIDS Coalition TO Unleash Power),

(52) The Big C/CA (for cancer),

(53) STD (Sexually-Transmitted Diseases) / MST (Maladies Sexuellement Transmissibles),

(54) MI (Myocardial infarction) / IDM (Infarctus du myocarde),

(55) $C A B G$ (coronary artery bypass graft) / PAC (pontage aorto-coronarien),

(56) RSI (Repetitive Strain Injury, aka tenosynovitis),

(57) PTSD (Post-Traumatic Stress Disorder),

(58) $T B$ (tuberculosis or consumption),

(59) VD (Veneral Disease),

(60) HSV (herpes), etc.

70 c) Circumlocution: circumlocution consists in using several words to say something that could be said more clearly and directly by using fewer words. This process is generally used to create euphemisms, as there seems to be a dilution of the signifier and one of the most useful ways of diluting the threatening effect of the original signifier, i.e. the orthophemism (the longer the mitigating euphemistic expression, the politer it is expected to be). No terminological examples have been found, probably do to the length of the expressions created, which makes it difficult for them to be completely lexicalized. In my corpus, it is interesting to note that circumlocution can also generate humorous words with a ludic dimension, as exemplified in the occurrences below:

(61) Patients in a terminal situation / Patients en (unités de) soins palliatifs, (62) A prolonged illness / A long battle against illness / Une longue et douloureuse maladie contre laquelle X s'est battu/e avec toutes ses forces et son courage,

(63) There's something wrong with my ticker / The old pump's not working too well (heart disease) / J'ai des problèmes de tuyauterie,

(64) Actually visually handicapped / Sight-deprived / Souffrant d'un trouble majeur de la vue / de l'audition (blind/deaf),

(65) I'm feeling poorly / Je ne me sens pas très bien, etc.

d) Rhyming slang: rhyming slang is a form of slang word construction mostly found in the English language that uses rhyme to create neologisms - and very often a ludic dimension added to the expression; it consists in replacing a common word with a phrase made up of two or more words, the last of which rhymes with the original word and, in almost all cases, omitting, from the end of the phrase, the secondary rhyming word. The most frequent form is the Cockney Rhyming Slang originating in the East End of London (see for example Smith [2015 (2011)]); Rhyming Slang is not a productive word-formation process in French, at least for disease euphemisms, and does not play a role in terminological designations:

(66) Band in the box / jack(-in-the-box) / Nervo and Knox (Rhyming Slang for pox)

(67) Bang and biff (Rhyming Slang for syph(ilis)),

(68) Hat and cap (Rhyming Slang for clap), etc.

e) Phonetic alteration: this process consists in altering the phonological structure of the signifier to make it less threatening; very few cases of this process are found for disease euphemisms, and the only cases I found are in English: 
(69) Pox (venereal disease, spelling alteration of pockes, plural of pocke, especially (after c. 1500) of syphilis; this is a case of terminological euphemism), etc.

(70) Emerads (hemorrhoids), etc.

f) Litotes a.k.a. negative of the contrary: this process consists in stating the same thing with antonyms, and very often results in circumlocution (see category c)), i.e. what Jamet \& Jobert [2010: 15] and Jamet [2010: 47] call "a dilution of the signifier"; several euphemisms exhibit a dilution of the signifier, as if it was one of the most useful ways of diluting its threatening effect too. The longer the mitigating euphemistic expression, the politer it is expected to be, even if the negation contained in the word is not perceived any longer, because it lost its original motivation (see demented / dément/e or imbecile / imbécile); those cases of demotivated euphemisms are often terminological nowadays:

(71) Demented / Dément/e (from Latin de- "out of" + mens "mind"),

(72) Imbecile / Imbécile (from Latin im- "without" + bacillum "small staff", literally "without a stick"),

(73) Insane / Insanity (the meaning of "insane" also seems to have narrowed from the latin in- ("not") + sanus ("healthy") and could originally be applied to all organs and body functions; today it only denotes a mental condition), etc.

(74) I'm not feeling so well/good / Be unwell / Be indisposed / Indisposition / Ne pas se sentir bien / Être indisposé/e / Indisposition,

(75) Out of sorts / Out of kilter / Déréglé/e,

(76) Be unsighted / Être non/mal voyant, etc.

74 All those examples tend to show - even if they are not all lexicalized - that taboo language exhibits a high lexical productivity, and that euphemisms and dysphemisms for disease and illness play a significant part in the lexical expansion of the domain, creating new lexemes or phrases to refer to an existing reality.

What needs finally to be highlighted is the frequent combination of word-formation processes in the euphemistic lexicon of diseases; let us take the adjective indisposed / indisposé as an example:

(77) indisposed (adj.)

c. 1400, "unprepared;" early 15c., "not in order," from in- (1) "not" + disposed; or else from Late Latin indispositus "without order, confused." From mid-15c. in English as "diseased;" modern sense of "not very well, slightly ill" is from 1590s. A verb indispose is attested from 1650s but perhaps is a back-formation of this, rather than its source, or from French indisposer. (https:// www.etymonline.com/word/indisposed)

(78) INDISPOSÉ, ÉE, part. passé et adj.

Étymol. et Hist. 1. Ca 1407 indisposé " gâté, mis en mauvais état » (J. GERSON, Dialogue spirituel ds Euvres, éd. P. Glorieux, t. VII, p. 166 : ame indisposée par pechié mortel); 1662 s'indisposer « se préparer mal (à quelque chose) » ([ LEMAISTRE DE SACY] De l'Imitation de Jesus-Christ, 1. 4, chap. 12, p. 384 : Celuy qui apres m'avoir receu se répand aussi-tost en des satisfactions exterieures, s'indispose beaucoup pour me recevoir); 2. a) 1455 indisposé « légèrement malade » (Arch. Nord, B 1686, fo50 ds IGLF : femme indisposée de sa personne); 1828 trans. « rendre légèrement malade » (MOZIN-BIBER); b) 1891 spéc. « qui a ses règles »(HUYSMANS, Là-bas, t. 1, p. 101); 3.1675 indisposé contre "fâché, mécontent » (MÉNAGE, Obs. sur la lang. fr., t. II, p. 446 ds BRUNOT t. 4, p. 484); av. 1679 s'indisposer contre " prendre en aversion » (RETZ, CEuvres, t. IV, p. 229 : 
elle s'indisposoit contre ses amants). Dér. de disposer* et de son part. passé disposé; préf. in-1*. Cf. lat. indispositus « mal ordonné, confus », lat. chrét. « mal préparé, surpris ». (http://www.cnrtl.fr)

\section{Latin; b) litotes a.k.a. negative of the contrary (see negative prefix in-); c) metonymy}

etymologies show that the euphemisms have been generated by a) borrowing from (the result for the disease).

\section{Concluding remarks: illness and disease euphemisms as pharmakon?}

77 As this article has endeavored to show, taboo language plays a role in the creation and expansion of the lexicon and represents a powerful source of word formation neology. As the corpus of taboo language for illness and disease exemplified, euphemisms and dysphemisms exhibit one of the fundamental dimensions of lexical creation and expansion: creativity, a factor which seems fundamental in the evolution of any given language, as noted by Keyes:

One might even argue that the need to come up with euphemisms for terms considered taboo is our most ancient source of verbal creativity. After all, it's far more difficult to say what one doesn't mean that what one does. An ability to do so - to create euphemisms and use them effectively - demonstrates a high order of intellectual sophistication [Keyes 2010: 248].

The taboo surrounding disease has always existed even if it changed targets and forms. In the beginning the taboo centered essentially on physical diseases for superstition-related reasons, but with the advent of medicine, and when mentally diseases started to be investigated, the reasons behind the creation of disease euphemisms changed. Previously incurable body diseases are no longer tabooed because they do not represent a threat to health anymore. However, they have been replaced by new diseases that we do not understand and do not know how to cure yet; they have become the new topic for taboo and euphemisms. As we have seen, the process of creating new taboos and euphemisms is cyclic; we can therefore imagine that in some decades the taboos we discussed today will be outdated and will have been supplanted by new, unknown diseases. Therefore, I disagree with Jeffries [1998: 218], when he writes that "[t]he taboo surrounding disease as largely faded during the twentieth century in Britain, but there have been fluctuations in the strength of a number of taboos during this period".

There is undeniably power in euphemisms, the power to soften the impact of a disease maybe too much (think of the euphemism brief illness to refer to suicide...). Disease euphemisms can be seen as pharmakon, from the Greek word pápuakov (phármakon), a composite of three meanings: remedy, poison, and scapegoat. This paradoxical role played by disease euphemisms is in keeping with the fact that their power is not infinite, as once a euphemism runs out of power due to the so-called "euphemism treadmill", it can become as bad as the word it replaces... and a new euphemism has to be created. That is the never-ending story of euphemistic language... and diseases... 


\section{BIBLIOGRAPHY}

ADAMS Robert M., 1985, "Soft Soap and the Nitty-Gritty", in ENRIGHT Dominique (ed.), Fair of Speech. The Uses of Euphemism, Oxford New York: Oxford University Press, 44-55.

ALLAN Keith \& BURRIDGE Kate, 1991, Euphemism and Dysphemism: Language Used as Shield and Weapon, New York: Oxford University Press.

ALLAN Keith \& BURRIDGE Kate, 2006, Forbidden Words. Taboo and the Censoring of Language, Cambridge: Cambridge University Press.

ALLAN Keith \& BURRIDGE Kate, "Euphemism, Dysphemism and cross-Varietal Synonymy": http://www.latrobe.edu.au/linguistics/LaTrobePapersinLinguistics/Vol\% 201/1AllanandBurridge.pdf

ALLAN Keith \& BURRIDGe Kate, CRESPO-FERNANDEZ Eliecer \& JAMEt Denis (eds.), 2012, “Euphemism as a Word-Formation Process", Lexis - Journal in English Lexicology \#7: http://lexis.revues.org/334 BAUER Laurie, 1993 (1983), English Word-Formation, Coll. "Cambridge textbooks in linguistics”, Cambridge: Cambridge University Press.

BAUER Laurie, 1994 (1988), Introducing Linguistic Morphology, Edinburgh: Edinburgh University Press.

BOWKER Lynne \& HERRERA Carolina, 2004, “A new Internet-based Communicative Setting: Exploring its Impact on Language for Special Purposes”, Lexicographica 20, 33-55.

BRown Penelope \& LEVINSON Stephen C., 1987, Politeness: Some Universals in Language Usage, Cambridge: Cambridge University Press.

BURCHFIELD Robert, 1985, “An Outline History of Euphemisms in English”, in ENRIGHT Dominique (ed.), Fair of Speech. The Uses of Euphemism, Oxford New York: Oxford University Press, 13-31. BURRIDGE Kate, 2004, Blooming English: Observations on the Roots, Cultivation and Hybrids of the English Language, Cambridge: Cambridge University Press.

BURRIDGE Kate, 2012, "Euphemism and Language Change: the Sixth and Seventh Ages", in "Euphemism as a Word-Formation Process", Lexis - Journal in English Lexicology \#7: http:// lexis.revues.org/355

CRAWFORD Allison, 2008, "Born Still: Euphemisms and the Double-Taboo of Women's Bodies and Death": http://homes.chass.utoronto.ca/ cpercy/courses/6362-CrawfordAllison.htm CRISP Quentin, 1984, Manners from Heaven: a Divine Guide to Good Behavior, London: Hutchinson. FAUCONNIER Gilles, 2002 (1997), Mappings in Thought and Language, Cambridge: Cambridge University Press.

FIRTH John Rupert, 1957, Papers in Linguistics 1934-1951, London: Oxford University Press. GILLIS Lynn, 1972, Human Behaviour in Illness: Psychology and Interpersonal relationships, London: Faber \& Faber.

GOFFMAN Erving, 1955, Interaction Ritual: Essays on Face-to-Face Behavior, London: Penguin University Books. 
GRICE Paul H., 1975, "Logic and Conversation", in COLE Peter \& MORGAN Jerry L. (eds.), Syntax and Semantics - Vol. 3: Speech Acts, University College London: Elsevier.

JAMET Denis \& JOBERT Manuel, 2010, « Juste un petit mot sur l'euphémisme... », in JAMET Denis \& JOBERT Manuel (eds.), Empreintes de l'euphémisme. Tours et détours, Actes du colloque des 29, 30 et 31 mai 2008, organisé à l'Université Jean Moulin - Lyon 3, Paris : L'Harmattan, 11-29.

JAMET Denis, 2010, « Historique et procédés linguistiques de l'euphémisme », in JAMET Denis \& JOBERT Manuel (eds.), Empreintes de l'euphémisme. Tours et détours, Actes du colloque des 29, 30 et 31 mai 2008, organisé à l'Université Jean Moulin - Lyon 3, Paris : L'Harmattan, 31-49.

JEFFRIES Lesley, 1998, Meaning in English. An Introduction to Language Study, Houndmills, Basingstoke, Hampshire and London: MacMillan Press Ltd.

JOHNSON Samuel, 1755, A Dictionary of the English Language, London: Consortium.

KANY Charles E., 1960, American-Spanish Euphemisms, Berkeley-Los Angeles: University of California Press.

KATZ Albert N., CACCIARI Cristina, GIBBS Raymond W. \& TURNER Mark, 1988, Figurative Language and Thought, Coll. “Counterpoints: Cognition, Memory, and Language”, New York - Oxford: Oxford University Press.

KELLER Rudi, 1994, On language change: The invisible hand in language, London: Routledge.

KEYES Ralph, 2010, Euphemania: our Love Affair with Euphemisms, Little: Brown and Company.

KÖVECSES Zoltán, 2002, Metaphor. A Practical Introduction, Oxford - New York: Oxford University Press.

LAKOFF George \& JOHNSON Mark, 1980, Metaphors We Live By, Chicago: The University of Chicago Press.

LAKOFF George, 1987, Women, Fire, and Dangerous Things. What Categories Reveal about the Mind, Chicago and London: The University of Chicago Press.

LIPKA Leonhard, 1990, An Outline of English Lexicology: Lexical Structure, Word Semantics, and WordFormation, Tübingen: Max Niemeyer Verlag.

LANGACKER Ronald W., 1987, Foundations of Cognitive Grammar, Vol. I, Theoretical Perspectives, Stanford: Stanford University Press.

MENCKEN Henry Louis, 1936 (1919), The American Language, New York: Knopf.

MONTSERRAT LÓPEZ Díaz \& SABLAYROLLES Jean-François, 2016, « Les néologismes euphémiques », La linguistique 2016/2, Vol. 52, Paris: Presses Universitaires de France.

PINKER Steven, 2002, The Blank Slate: The Modern Denial of Human Nature, New York: Viking.

PLAG Ingo, 2003, Word-Formation in English, Coll. “Cambridge Textbooks in linguistics”, Cambridge: Cambridge University Press.

PRUVOST Jean \& SABLAYRolLES Jean-François, 2012 (2003), Les néologismes, Coll. « Que sais-je ? ", Paris: PUF.

REUTNER Ursula, 2009, Sprache und Tabu. Interpretationen zu französischen und italienischen Euphemismen, Tübingen: Max Niemeyer. 
RICHARDT Susan, 2005, Metaphor in languages for special purposes: The function of conceptual metaphor in written expert language and expert-lay communication in the domains of economics, medicine, and computing, Frankfurt am Main: Peter Lang.

SANTAEMILIA José (ed.), 2005, The Language of Sex: Saying \& Not Saying, Valencia: Universtitat de Valencia.

SAUSSURE Ferdinand de, 1972 (1916), Cours de linguistique générale, Paris: Bibliothèque scientifique Payot.

SCHMID Hans-Jörg, 2016, English morphology and word-formation: An introduction, Berlin: Schmidt Verlag.

SMITH Daniel, 2015 (2011), Cockney Rhyming Slang: The Language of London, London: Michael O'Mara Books Limited.

SONTAG Susan, 1978, Illness as Metaphor (1978) and AIDS and Its Metaphors (1989), New York: Farrar, Straus and Giroux.

SWEETSER Eve E., 1990, From Etymology to Pragmatics. Metaphorical and Cultural Aspects of Semantic Structure, Coll. "Cambridge Studies in Linguistics" \#54, Cambridge: Cambridge University Press. TOURNIER Jean, 1985, Introduction descriptive à la lexicogénétique de l'anglais contemporain, ParisGenève: Champion-Slatkine.

TOURNIER Jean, 1991a, Précis de lexicologie anglaise, Paris: Nathan Université.

TOURNIER Jean, 1991b, Structures lexicales de l'anglais : guide alphabétique, Paris: Nathan Université.

\section{Corpus}

ANDERSON Douglas M. (chief lexicographer), 1994 (1940), Dorland's Illustrated Medical Dictionary, Philadelphia: WB Saunders Co.

COCA (Corpus of Contemporary American English): https://corpus.byu.edu/coca/

HOLDER R. W., 2003 (1995), Oxford Dictionary of Euphemisms. How Not to Say What You Mean, New York, Oxford University Press.

MC DONALD James, 1988, A Dictionary of Obscenity, Taboo \& Euphemism, London: Sphere Books Ltd. NEANMAN Judith S. \& SILVER Carole G., 1991, The Wordsworth Book of Euphemism, Wordsworth Editions Ltd.

RAWSON Hugh, 1981, A Dictionary of Euphemisms and Other Double Talk. Being a Compilation of Linguistic Fig Leaves \& Verbal Flourishes for Artful Users of the English Language, New York: Crown Publishers, Inc.

Sketch Engine Corpora: https://www.sketchengine.eu/

\section{NOTES}

1. Notable exceptions (including studies on taboo in other languages) can yet be mentioned, such as the remarks on euphemism in Keller [1994], as well as Reutner [2009] and especially Montserrat López \& Sablayrolles [2016] for French. According to Keller, euphemism can even be considered to be a key factor of language change, and he provides a clear description of the wearout effects that can be regularly observed in euphemisms. Other studies have been carried out in the field of cognitive sociolinguistics (see for example Andrea Pizaro's workshop at the 
2015 International Cognitive Linguistics Conference) or in the fields of computational linguistics (see for example Kris Heylen's computational analyses).

2. H. L. Mencken [1936 (1919): 302] called the nineteenth century "the Golden Age of Euphemism".

3. Many thanks to John Humbley who mentioned that this is one of the main difficulties of French-English medical translation: how should "maladie" be translated? "sickness", "illness", "disease", "condition", etc.?

4. Sontag [1990: 104] writes that "[i]t seems that societies need to have one illness which becomes identified with evil, and attaches blame to its "victims," but it is hard to be obsessed with more than one.

5. That is a reason why AIDS was initially labeled Gay Cancer and Gay Plague.

6. Sontag [1990:126] writes that "[t]he most terrifying illnesses are those perceived not just as lethal but as dehumanizing, literally so".

7. According to Richardt [2005], the conceptual metaphor DISEASE IS WAR is not restricted to cancer but is used to talk about disease in general.

8. For more details, see Burridge [2012].

9. Many thanks to John Humbley for pointing out this fact.

10. See words such as laser (Light Amplification by Stimulated Emission of Radiation) or radar ( RAdio Detection And Ranging).

11. Another reason accounting for shortening is advocated by Bowker \& Herrera [2004: 44]: patients often shorten the name of their disease or condition to create a "connivance effect": lap (laparoscopy), o (ovulation), BF (breastfeeding), $\mathrm{m} / \mathrm{c}$ (miscarriage), pg (pregnant), mets (metastases), ultra (ultrasound), mammo (mammogram), etc. Thank you to John Humbley for mentioning this reference.

\section{ABSTRACTS}

According to Allan \& Burridge [1991: 11], "[a] euphemism is used as an alternative to a dispreferred expression, in order to avoid possible loss of face: either one's own face or, through giving offence, that of the audience, or some third party." The word "alternative" seems to imply that there is always a choice for speakers, according to the situation of utterance, the interlocutor(s), the register, etc. Yet, in some cases, there does not seem to be much choice, and some euphemisms are completely lexicalized as they have imposed themselves as the only acceptable ways to refer to a given referent or a given notion. This may be the case for politically-correct terms for instance, or for euphemisms referring to notions that are deemed too shocking or painful to be directly mentioned, such as diseases.

This article aims to discuss the aspects of word-formation process in the euphemistic lexicon of physical and mental illnesses in English and in French, by resorting to a comparative analysis. I will try and show that if some euphemistic neologisms are generated to circumvent the taboo surrounding diseases and illnesses, some others act as real terminological creations and enable to play a role in structuring the domain.

Selon Allan \& Burridge [1991: 11], « [un] euphémisme est utilisé comme alternative face à une expression moins désirable, afin d'éviter une perte de face, que ce soit sa propre face, ou bien celle de l'interlocuteur, ou d'une quelconque autre personne»(ma traduction). Le terme 
«alternative» semble impliquer qu'il existe toujours un choix pour les locuteurs, selon la situation d'énonciation, les interlocuteurs, le registre, etc. Cependant, dans plusieurs cas, il ne semble pas y avoir de réel choix, et certains euphémismes sont totalement lexicalisés dans le sens où ils se sont imposés comme les uniques façons de dénoter tel ou tel référent ou telle ou telle notion. C'est ainsi le cas des termes issus du politiquement correct, par exemple, ou des euphémismes utilisés dans la dénomination de notions jugées trop choquantes ou douloureuses pour être mentionnées directement, comme les maladies.

Cet article se propose de mettre au jour les aspects de la création néologique dans le domaine du lexique d'origine euphémique des maladies physiques et mentales en anglais et en français. Je montrerai que si certains néologismes euphémiques sont générés pour court-circuiter le tabou autour de la maladie, d'autres agissent tels de réels néologismes terminologiques en ce qu'ils permettent de structurer le domaine.

INDEX

Mots-clés: tabou, langage tabouique, euphémisme, dysphémisme, maladie, néologie, néologisme, motivation, langue anglaise, langue française

Keywords: taboo, taboo language, euphemism, dysphemism, illness, disease, neology, neologism, motivation, English language, French language

\section{AUTHOR}

DENIS JAMET

Université de Lyon (UJML3) \& University of Arizona

denis.jamet@univ-lyon3.fr 